\section{More than mere musings: Russell's reflections on education as philosophy}

\author{
by Howard Woodhouse
}

WILliam HARE's PAPER “Russell's Reflections on Education: Relevant or Remote?" in the Summer 1987 issue of Russell is a welcome addition to the literature on Russell's educational thought. Hare argues for the reinstatement of Russell as a central figure in modern philosophy of education: in his own words, "an important contributor to the development of the discipline". His argument is thorough, analytic, and level-headed. Unlike most commentators, he shows Russell to have applied the same method of scientific philosophy in his educational thought as he did in his philosophical writings.

Hare shows this with regard to two main questions:

I. Russell's concept of education upholds the search for truth as a mean between dogmatism and scepticism. The basis of this search is the scientific method as "empirical, tentative, and undogmatic". Indeed, Hare shows that Russell's calls to philosophers to take action to help end the arms race during the I960s were consistent with his belief that it was still possible for the scientific rationalist to act in a direct manner: provided, that is, that the evidence supports his or her beliefs (pp. I I-I2).

2. Russell's concept of teaching and learning is based on the concept of reverence, which is simply a respect for the child's independence (pp. I 8-I9). Hare sees a link here between Russell's notion of reverence and the emphasis upon the need for respect for the student and the importance of reason in teaching that is exemplified in the more recent work of Israel Sheffler and Harvey Siegel (pp. 22-3).

I wish now to raise some critical questions concerning these and other points that Hare raises.

Taking reverence first, I find that Hare makes of it far too intellectual a concept. Indeed, he explicitly denies there to be any romantic elements to its meaning: as he puts it, there is no "romantic tender-mindedness" (p. 2I) in Russell's conception. I think that he is mistaken here. First, the chapter from Principles of Social Reconstruction in which Russell articulates his notion of reverence is hardly concerned with formal education at all. His major concern is to articulate the kind of climate necessary in education for the constructive growth that lies at the basis of healthy human beings. This is rooted in the principle of growth from which all human activity springs: a conception clearly Romantic in its origins and its implications for education and society. If we wish to understand Russell's ideas on these matters, it seems that we should not exclude those aspects that do not fit with a purely "rationalist" interpretation of his work. Such an interpretation leads to a denigration of the emotions, of care, and of expressive understanding both in our interpretation of Russell's work and in education in general. Indeed, this is the criticism of Russell's later "clockwork behaviourism" made by Katharine Tait and Brian Hendley. Furthermore, both these writers suggest that any notion of the education of the spirit was missing by the time that Russell ran Beacon Hill School (pp. 2I-2). Yet spirit was one of the three constituent elements of the individual in the earlier Principles of Social Reconstruction: further evidence that Russell's educational thought was distinctly Romantic in I9I6.

Second, Russell's account of the scientific method leads to a conviction that "towards facts, submission is the only rational attitude" (Russell, "The Value of Free Thought", quoted on p. 12). This, indeed, was the basis of his disagreement with John Dewey: that science was based on statements that were (as far as possible) true on the basis of their correspondence with fact, not, as Dewey upheld, on the basis of "warranted assertability".

Russell's defence of pristine facts as the objective basis of science appears questionable in light of the work of Thomas Kuhn and others. Kuhn argues, among other things, that those facts that are selected, measured, and predicted in science are based upon "paradigms" (i.e. models or theories) that determine what is accepted as fact within the scientific community. These paradigms are normative in nature and determine the procedures and rules that govern a particular discipline and the behaviour of the scientific community towards what is to count as scientific fact. Thus to base an account of the scientific method upon facts as the ultimate arbiter of which theories or paradigms are to be accepted is to ignore the normative aspects of science and the scientific community.

A third feature of Russell's educational thought to which Hare draws little or no attention are the changes that the theory underwent. As a result there is little sense of a historical development taking place within the theory. This, despite the fact that Hare refers to articles of Russell's as far apart as I9I3 and I96I (p. Io). The impression given is that there was one uniform view espoused by Russell in his educational thought, which, I would suggest, is only true of his account of the scientific method. Other aspects of Russell's educational thought that underwent profound changes were his account of the individual and his or her relation to society. As I have already pointed out, the educational romanticism of Principles of Social Reconstruction conceived of the individual as composed of a triad of instinct, mind, and spirit. In contrast, the behaviourist account of the individual espoused in On Education in 1926 was based 
on an almost completely different triad: reflex, instinct, and habit. While it would have been impossible for Hare to have given a full account of all such changes in his paper, he could nevertheless have indicated to the reader that some change occurred in Russell's thought.

Fourth, I have some reservations about the description of the purpose of Russell's work being "the traditional philosophical one of clarification and justification" (p. 24). If this is true, it is surely only in the broadest possible sense. For, if what is meant by "clarification" is conceptual analysis, then surely this was neither Russell's "task" nor that of traditional philosophy. Russell was quite open about his antipathy towards analytic (or linguistic) philosophy, which he consistently saw as trivial and unscientific in its desire to accept as given the utterances of "ordinary language". Furthermore, the kind of conceptual clarification undertaken by analytic philosophers was, for him, unscientific because of its steadfast refusal to take notice of any advances in the natural sciences. The claim by his former student, Ludwig Wittgenstein, that there were no genuine philosophical problems, only linguistic ones, was as unacceptable to Russell as it later proved to Sir Karl Popper, who wrote of the claim as follows: "The view of many philosophers, and, especially, it seems, Wittgensteinians, is that if a problem is soluble, it cannot have been philosophical". The point is that it is far from clear both to Russell and other distinguished philosophers that the task of philosophy is clarification and analysis. For them this is too insignificant a role for philosophy to play. Could this be one of the reasons for Russell's having fallen out with the mainstream in both modern philosophy and educational thought? And could this be one of the reasons for a contemporary philosopher like William Hare having to reclaim Russell as an important member of the discipline of philosophy of education lest he become a "dinosaur out of place" in our culture?

\section{Independent Studies}

University of Waterloo 